\title{
Empirical Study of Protein Feature Representation on Deep Belief Networks Trained with Small Data for Secondary Structure Prediction
}

This paper was downloaded from TechRxiv (https://www.techrxiv.org).

\section{LICENSE}

CC BY-NC-SA 4.0

SUBMISSION DATE / POSTED DATE

29-01-2021 / 02-02-2021

\section{CITATION}

Rashid, Shamima (2021): Empirical Study of Protein Feature Representation on Deep Belief Networks Trained with Small Data for Secondary Structure Prediction. TechRxiv. Preprint. https://doi.org/10.36227/techrxiv.13663583.v1

$\mathrm{DOI}$ 


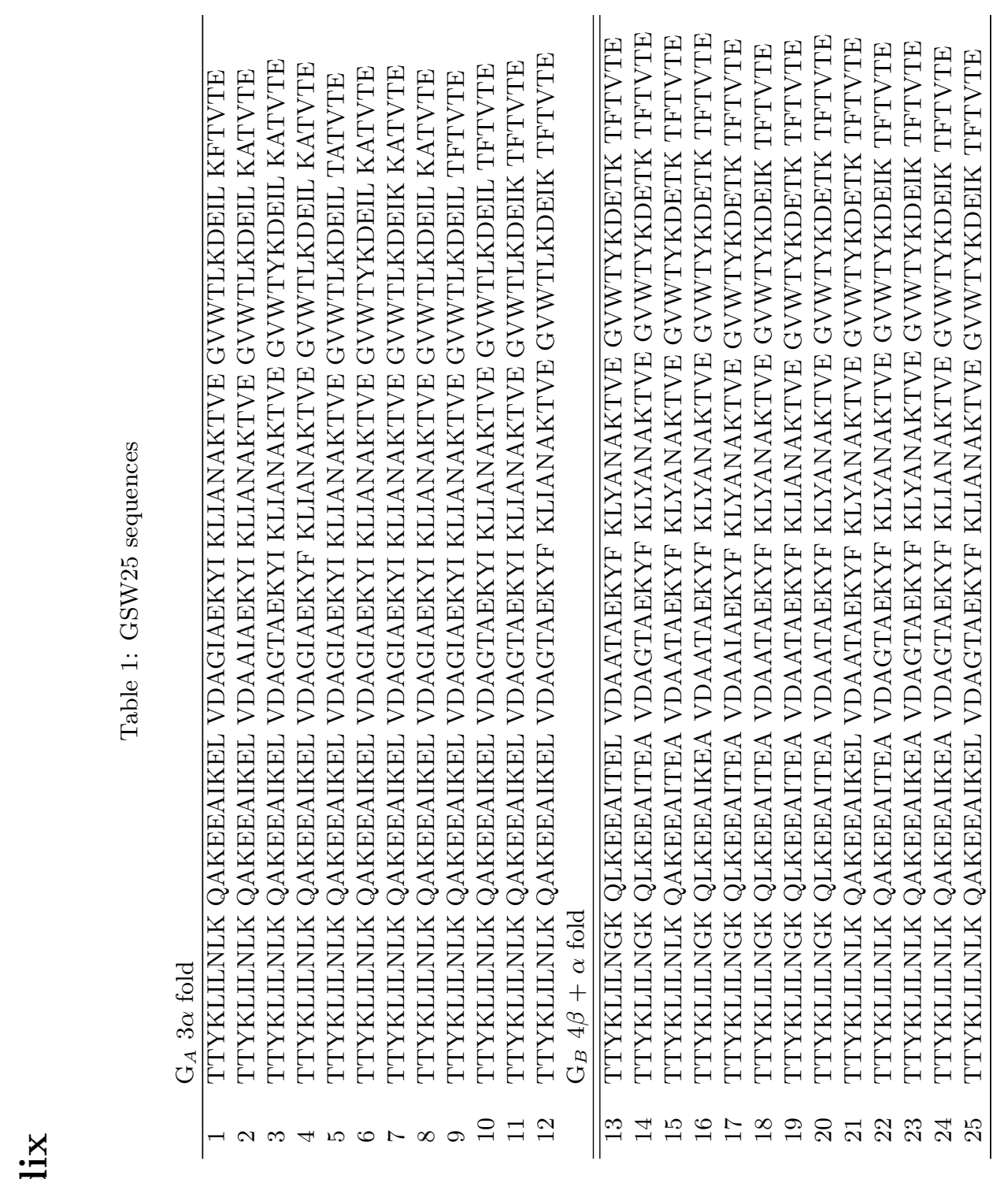

